\title{
Tissue Plasminogen Activator Antigen Measurement
}

National Cancer Institute

\section{Source}

National Cancer Institute. Tissue Plasminogen Activator Antigen Measurement. NCI

Thesaurus. Code C81993.

The determination of the amount of tissue plasminog en activator antigen present in a sample. 